\title{
Melatonin-induced KiSS1 expression inhibits triple-negative breast cancer cell invasiveness
}

\author{
TAE-HUN KIM and SUNG-GOOK CHO \\ Department of Biotechnology, Korea National University of Transportation, Jeungpyeong, \\ Chungcheongbuk 368-701, Republic of Korea
}

Received April 19, 2016; Accepted April 6, 2017

DOI: $10.3892 / \mathrm{ol} .2017 .6434$

\begin{abstract}
Breast cancer is one of the most common types of cancer in women, and its metastasis increases the risk of mortality. Melatonin, a hormone that regulates the circadian rhythm, has been revealed to inhibit breast cancer growth and metastasis. However, its involvement in highly metastatic triple-negative breast cancer cells is yet to be elucidated. The present study demonstrated that melatonin inhibited the metastatic abilities of triple-negative breast cancer cells and prolonged its inhibitory effect via the expression of kisspeptin (KiSS1), which is a suppressor of metastasis. Melatonin at concentrations ranging from $1 \mathrm{nM}$ to $10 \mu \mathrm{M}$ did not affect the proliferation of metastatic MDA-MB-231 and HCC-70 triple-negative breast cancer cells. However, melatonin repressed invasiveness in triple-negative breast cancer cells. Additionally, conditional medium from melatonin-treated MDA-MB-231 cells repressed the invasiveness of triple-negative breast cancer cells. Melatonin promoted the production of KiSS1, a metastasis suppressor encoded by the KiSS1 gene. In addition, melatonin increased KiSS1 expression via the expression and transcriptional activation of GATA binding protein 3. Silencing of KiSS1 weakened melatonin inhibition of breast cancer cell invasiveness. Therefore, the present study concluded that melatonin activates KiSS1 production in metastatic breast cancer cells, suggesting that melatonin activation of KiSS1 production may regulate the process of breast cancer metastasis.
\end{abstract}

\section{Introduction}

Melatonin, a hormone secreted from the pineal gland in the brain at night, mainly regulates the circadian rhythm through

Correspondence to: Professor Sung-Gook Cho, Department of Biotechnology, Korea National University of Transportation, 61 University Road, Jeungpyeong, Chungcheongbuk 368-701, Republic of Korea

E-mail: chosg@ut.ac.kr

Key words: kisspeptin, KISS1 receptor, melatonin, GATA binding protein 3, triple-negative breast cancer seven transmembrane G-protein-coupled receptors, melatonin receptor type 1A (MT1) and melatonin receptor type 1B (1-7). In addition, melatonin is produced by other organs, including the skin, bone marrow and lymphocytes $(6,8)$. Breast cancer is frequently identified in women, and demonstrates high mortality once metastasized (9-11). Patients with breast cancer present with low levels of melatonin, which may be due to disruptions of the circadian rhythm (4,12-15). Melatonin treatment has been suggested to halt breast cancer progression and improve quality of life in patients with breast cancer $(16,17)$.

Breast cancer is subcategorized by the expression patterns of hormone receptors and human epidermal growth factor $2(7,18)$. Triple-negative breast cancer is aggressive and associated with poor prognosis (18). Triple-negative breast cancer cells are also invasive, resulting in higher metastatic rates (18). However, therapeutic options are lacking. Expression levels of MT1 are associated with survival rates in African American and Caucasian women, suggesting that melatonin may be a therapeutic option (19). However, the effect of melatonin on triple-negative breast cancer cells remains largely unknown.

Kisspeptin (KiSS1), a gene product of KiSS1, is known to regulate the onset of puberty and to suppress cancer metastasis $(20,21)$. KiSS1 expression levels are increased in primary breast cancer lesions but reduced in metastatic lesions (22-25), suggesting that KiSS1 may serve pleiotropic functions during breast cancer development and metastasis (20). While it was revealed that melatonin regulates KiSS1 expression in the hypothalamus in the brain $(26,27)$, an association between melatonin and KiSS1 in cancer has not been identified. While $1 \mathrm{mM}$ melatonin treatment inhibited metastatic functions, including migration and invasion in triple-negative MDA-MB-231 breast cancer cell lines, the pharmacological concentration of melatonin also reduced the cell viability and caused apoptosis (28-30). In addition, physiological concentrations of melatonin only reduced the viabilities of less invasive, non-triple-negative breast cancer cells $(28,31,32)$, which may be due to different MT1 expression levels in less or highly invasive breast cancer cells (33). Therefore, whether melatonin directly inhibits the invasion of highly metastatic triple-negative breast cancer cells remains unclear.

The GATA family of transcription factors is crucial for determining cell fate, and is composed of six conserved members that bind to the DNA sequence (A/T)GATA(A/G) (34-37). 
GATA binding protein 3 (GATA3) has emerged as crucial for mammary luminal cell fate $(37,38)$. GATA3 expression patterns in breast cancer appear to correlate with the expression patterns of estrogen receptors and progesterone receptors $(39,40)$. Therefore, less invasive, hormone-positive breast cancer is likely to express high levels of GATA3 $(40,41)$. Inversely, patients with highly invasive triple-negative breast cancer may present with low levels of GATA3, which appears to be maintained during metastasis $(41,42)$.

The aim of the present study was to understand the function of melatonin in triple-negative breast cancer cells. To investigate the effect of melatonin on breast cancer cell invasiveness, highly metastatic triple-negative breast cancer cells were treated with melatonin at concentrations ranging from $1 \mathrm{nM}$ to $10 \mu \mathrm{M}$. Melatonin at concentrations of $100 \mathrm{nM}$ to $10 \mu \mathrm{M}$ inhibited triple-negative breast cancer cell migration and invasion with no effect on cell proliferation. In addition, melatonin-induced KiSS1 expression prolonged its inhibition of metastatic abilities, as confirmed by promoter assays and KiSSI silencing in the cells. It was also revealed that melatonin increased the expression levels and activated transcriptional activity of GATA3 for KiSS1 expression. Therefore, the results of the present study suggested that melatonin prolongs the inhibitory effect on breast cancer metastasis by activating GATA3-mediated KiSS1 expression.

\section{Materials and methods}

Cell lines and reagents. MDA-MB-231, HCC-70 and 293T cells (American Type Culture Collection, Manassas, VA, USA) were cultured in Dulbecco's modified Eagle's medium supplemented with 5\% fetal bovine serum (Gibco; Thermo Fisher Scientific, Inc., Waltham, MA, USA) and $1 \%$ penicillin/streptomycin solution (Gibco; Thermo Fisher Scientific, Inc.). Melatonin was purchased from Sigma-Aldrich; Merck KGaA (Darmstadt, Germany) and diluted in distilled water to a final concentration of $50 \mathrm{ug} / \mathrm{ml}$. KiSS1 was obtained from Phoenix Pharmaceuticals, Inc. (Burlingame, CA, USA).

In silico promoter analyses, reporter assays and chromatin immunoprecipitation assays. The human KiSS1 promoter region was analyzed in silico using the AliBaba2 prediction tool (http://www.gene-regulation. com/pub/programs/alibaba2/index.html). Different sizes of KiSS1 promoter regions, constructed in pGL3 plasmids (Promega Corporation, Madison, WI, USA), were used in luciferase assays. Each promoter region was amplified by PCR and cloned into pGL3 plasmids. These plasmids were named KiSS1-luc plasmids and the pGL3 backbone was the same as the KiSS1-luc. The cells were transfected with KiSS1-luc plasmids using Lipofectamine 2000 (Invitrogen; Thermo Fisher Scientific, Inc.), according to the manufacturer's instruction, and subjected to the luciferase assays following the manufacturer's protocol (Dual-Luciferase Reporter Assay system; Promega Corporation). Luciferase assays were performed in triplicate, and three times independently. Chromatin immunoprecipitation assays were performed according to the manufacturer's protocol (ChIP Kit Magnetic One-Step; Abcam, Cambridge, UK). The GATA3 antibody purchased from Abcam (cat no. ab199428; dilution, 1:25), were used for the chromatin immunoprecipitation assays. The GATA3 binding region was amplified using a primer set as follows: Forward, 5'-CCAAAG TAAGTC-3' and reverse, 5'-CTTCCCTCCAGGG-3'.

RNA and protein analysis. For analyzing RNAs, $5 \times 10^{6}$ cells were lysed with TRIzol (Invitrogen; Thermo Fisher Scientific, Inc.), and cDNA was amplified with routine PCR procedures: For the RNA analysis, the present study used the Reverse Transcription system (Promega Corporation). Reverse transcription was performed using oligo $(\mathrm{dT})_{15}$ primers at $42^{\circ} \mathrm{C}$, according to the manufacturer's protocol. Samples were incubated for $10 \mathrm{~min}$ at $25^{\circ} \mathrm{C}$, reverse transcribed for $30 \mathrm{~min}$ at $42^{\circ} \mathrm{C}$ and then placed for $5 \mathrm{~min}$ at $95^{\circ} \mathrm{C}$ for the inactivation of the reverse transcription. Real-time PCR was performed using SYBR-Green Real-Time PCR Master Mix (cat no. 4309155; Thermo Fisher Scientific, Inc.), according to the manufacturer's protocol. Samples were incubated for $10 \mathrm{~min}$ at $95^{\circ} \mathrm{C}$, denatured for $15 \mathrm{sec}$ at $95^{\circ} \mathrm{C}$ and annealed and extended for $1 \mathrm{~min}$ at $60^{\circ} \mathrm{C}$, for 40 cycles. KiSSI mRNA expression levels was examined using the primer sequences as follows: Forward, 5'-GCCCACCATGAACTCACTG-3' and reverse, 5'-CTGCCCCGCACCTGCG-3'. $\beta$-actin mRNA was also amplified with primers, as follows: Forward, 5'GGCTCC GGCATGTGCAAGGC3' and reverse, 5'CTGCCCCGCACC TGCG3', as an internal control. PCRs were performed using a LightCycler 480 Instrument II, and relative quantifications were automatically conducted by the efficiency method $(43,44)$ in LightCycler 480 software 1.5 (both from Roche Diagnostics, Indianapolis, IN, USA). For analyzing the protein levels, $1 \times 10^{6}$ cells were lysed using radioimmunoprecipitation buffer for $30 \mathrm{~min}$ on ice, and centrifuged at $20,000 \mathrm{x} \mathrm{g}$ for $10 \mathrm{~min}$ at $4^{\circ} \mathrm{C}$. Subsequent to measuring the protein concentration with Pierce BCA protein assay kit (Pierce; Thermo Fisher Scientific, Inc.) according to the manufacturer's protocol, $30 \mu \mathrm{g}$ protein was loaded and processed with 6-10\% SDS-PAGE, and transferred to polyvinylidene fluoride membranes. Subsequent to blocking with $5 \%$ milk for $1 \mathrm{~h}$ at room temperature, the membrane was incubated with KiSS1 (dilution, 1:250), GATA3 (dilution, 1:500) and $\beta$-actin (dilution, 1:500) antibodies for an additional $1 \mathrm{~h}$ at room temperature. $\beta$-actin was detected as an internal control. The KiSS1, GATA3 and $\beta$-actin antibodies were obtained from Santa Cruz Biotechnology, Inc. (Dallas, TX, USA). The membranes were then incubated in secondary antibodies conjugated to horseradish peroxidase (anti-rabbit, cat no. 7074; anti-mouse, cat no. 7076; Cell Signaling Technology, Inc., Danvers, WI, USA) at 1:2,000 in dilution for $1 \mathrm{~h}$ at room temperature. Band detection was performed using LumiGLO chemiluminescent reagent and peroxidase (cat no. 7003; Cell Signaling Technology, Inc.). Western blot experiments were replicated at least three times independently. For relative quantifications, ImageJ software (version 1.50) was used (National Institutes of Health, Bethesda, MA, USA).

Cell proliferation, migration and invasion assays. Cells $\left(1 \times 10^{5}\right)$ were cultured in 96-well plates, treated with different concentrations $\left(0,1,10,10^{2}, 10^{3}\right.$ and $\left.10^{4} \mathrm{nM}\right)$ of melatonin for $48 \mathrm{~h}$, and then subjected to cell proliferation assays using the CyQUANT Cell Proliferation Assay kit (Molecular Probes; Thermo Fisher Scientific, Inc.) according to the manufacturer's protocol. Experiments were performed in quadrate 
A

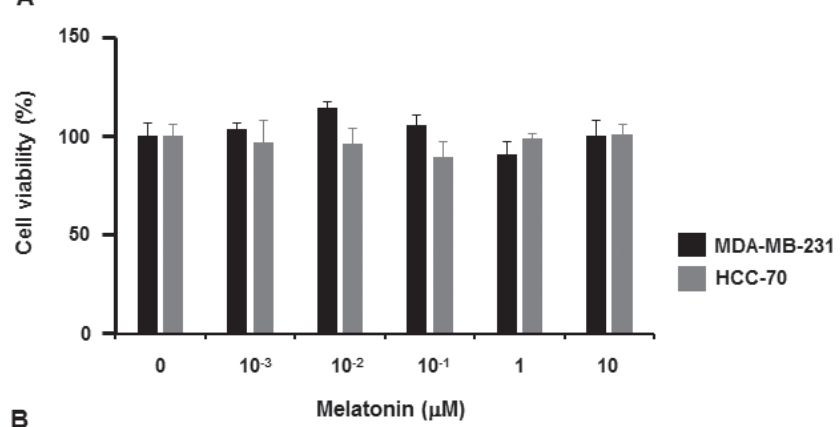

B

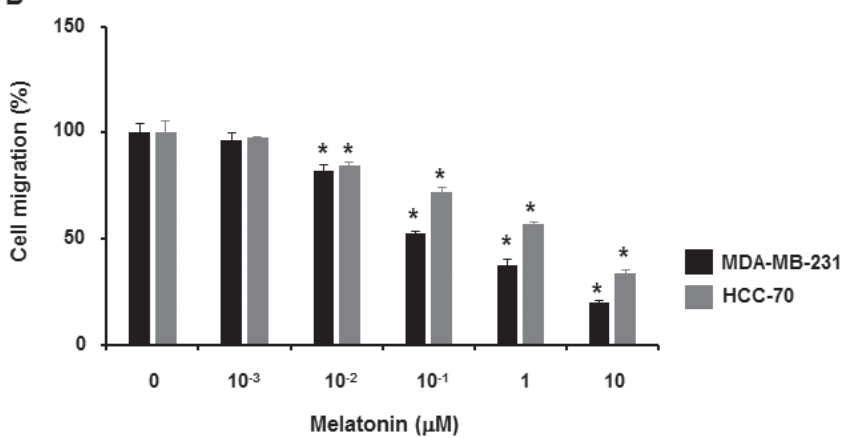

C

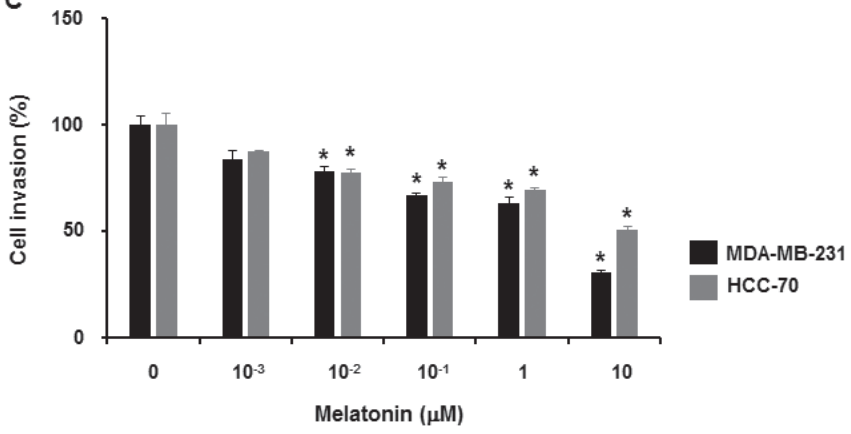

Figure 1. Melatonin inhibits metastasis in triple-negative breast cancer cells. (A) MDA-MB-231 and HCC-70 cells were treated with melatonin at the indicated concentrations for $48 \mathrm{~h}$ and then subjected to proliferation assays. (B) MDA-MB-231 and HCC-70 cells were scratched and then treated with different concentrations of melatonin for $24 \mathrm{~h}$. Migrated cells on the wounding regions were counted. (C) MDA-MB-231 and HCC-70 cells were subjected to a Matrigel invasion assay, and the invading cells were counted. Data are presented as the mean \pm standard deviation. ${ }^{*} \mathrm{P}<0.05$ vs. $0 \mu \mathrm{M}$.

and independently repeated in triplicate. For cell migration, $3 \times 10^{5}$ cells were cultured in 6 -well plates and scratched when the confluence reached $\sim 80 \%$. The cells were treated with $10 \mu \mathrm{M}$ melatonin for $24 \mathrm{~h}$ at $37^{\circ} \mathrm{C}$, and then the number of migrated cells was counted. Experiments were performed in triplicate. Non-treated cells were used as a control in this migration assay. To examine invasiveness, cells were cultured in the upper chambers of Matrigel-precoated Transwell plates, and then treated with melatonin at $10 \mu \mathrm{M}$ for $24 \mathrm{~h}$ at $37^{\circ} \mathrm{C}$. The cells in the upper chamber were removed with a swab, and cells that had invaded through the Matrigel were stained with $0.4 \%$ crystal violet and counted. Experiments were performed in triplicate. Non-treated cells were used as a control. The migration and invasion assays were observed using a Zeizz Axiovert inverted microscope and images were analyzed using Zen software version 3.00 (Carl Zeizz, Oberkochen, Germany). A total of 4 fields were randomly selected and the invaded cells were counted. Cells were transfected with pcDNA (Invitrogen; Thermo Fisher Scientific, Inc.), a pcDNA-GATA3 (human full length GATA3 sequence; NM_001002295.1), control small interfering (si) RNA-A (cat no. sc-37007) or KiSS1 siRNA (cat no. sc-37443) (both from Santa Cruz Biotechnology, Inc.) for $24 \mathrm{~h}$ using Lipofectamine $2000^{\circledR}$ (Invitrogen; Thermo Fisher Scientific, Inc.) according to the protocol of the manufacturer, and then subjected to the cell analyses including cell migration and invasion assays. In the overexpression analysis, the pcDNA empty vector was used as the control plasmid.

Statistical analysis. Statistical analysis was performed using unpaired Student's t-tests or one-way analysis of variance with a post-hoc Tukey's test was performed using SPSS version 22 (IBM Corp., Armonk, NY, USA). Results were expressed as the mean \pm standard deviation or mean \pm standard error, and $\mathrm{P}<0.05$ was considered to indicate a statistically significant difference.

\section{Results}

Melatonin inhibits metastasis without affecting cell proliferation. To examine the effect of melatonin on the proliferation of triple-negative MDA-MB-231 and HCC-70 breast cancer cells, the cells were treated with melatonin at different concentrations $\left(0,1,10,10^{2}, 10^{3}\right.$ and $\left.10^{4} \mathrm{nM}\right)$ for $48 \mathrm{~h}$. Data from the cell proliferation assays demonstrated that melatonin did not affect the proliferation of triple-negative breast cancer cells (Fig. 1A).

Next, whether melatonin affects triple-negative breast cancer cell migration and invasion was examined. When triple-negative breast cancer cells were treated with melatonin at different concentrations $\left(0,1,10,10^{2}, 10^{3}\right.$ and $\left.10^{4} \mathrm{nM}\right)$ for $24 \mathrm{~h}$, it was revealed that treatment with $10 \mathrm{nM}$ to $10 \mu \mathrm{M}$ melatonin reduced cell migration (Fig. 1B). Likewise, $10 \mathrm{nM}$ to $10 \mu \mathrm{M}$ melatonin treatment inhibited the invasiveness of triple-negative breast cancer cells (Fig. 1C).

Melatonin induces KiSS1 expression via GATA3. The results of the present study revealed that melatonin inhibited the migration and invasion of triple-negative breast cancer cells. This result was consistent with a previous study (28). Nevertheless, the mechanisms by which the inhibitory effect of melatonin is prolonged were not investigated. It was assumed that melatonin may maintain its inhibitory effect by inducing the production of anti-invasive proteins. Therefore, the effect of conditional medium from the cells treated with melatonin on the invasiveness of the breast cancer cell lines was examined. Conditioned medium from MDA-MB-231 cells treated with $10 \mu \mathrm{M}$ melatonin also repressed MDA-MB-231 cell invasiveness (Fig. 2A), which indicated that melatonin may prolong its inhibitory effect by inducing the production of releasing factors that suppress invasiveness.

KiSS1 is known to inhibit cancer cell migration and invasion, resulting in a suppression of cancer metastases (20). Thus, whether melatonin affects KiSS1 expression in triple-negative breast cancer cells was examined. Melatonin increased KiSS1 protein expression in MDA-MB-231 and HCC-70 cells (Fig. 2B). 

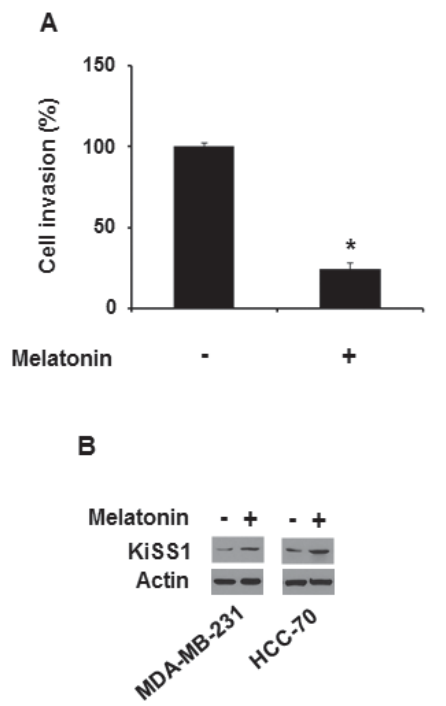

Figure 2. Melatonin induces KiSS1 production. (A) MDA-MB-231 cells were treated with $10 \mu \mathrm{M}$ melatonin for $24 \mathrm{~h}$. MDA-MB-231 cells were treated with conditioned medium for another $24 \mathrm{~h}$ and then subjected to Matrigel invasion assay. The invading cells were counted. (B) MDA-MB-231 and HCC-70 cells were treated with $10 \mu \mathrm{M}$ melatonin for $24 \mathrm{~h}$ and then subjected to western blot analysis. Data are presented as the mean \pm standard deviation. " $\mathrm{P}<0.05$ vs. $0 \mu \mathrm{M}$. KiSS1, kisspeptin.

To examine whether melatonin affected KiSS1 expression at the transcriptional level, luciferase assays were performed in 293T cells transfected with different KiSS1-luc constructs. Treatment with $100 \mathrm{nM}$ melatonin increased the luciferase activity of $-900 \mathrm{bp}$ of the KiSS1 promoter region (pKiSS1-900-luc) by 7-fold, while not affecting the KiSS1 promoter region of either $-1 \mathrm{~kb}$ or $-600 \mathrm{bp}$ (Fig. 3A). Thus, it was hypothesized that melatonin may affect a certain transcriptional factor that may bind to the KiSS1 promoter region between $-900 \mathrm{bp}$ and $-600 \mathrm{bp}$. When pKiSS1-900-luc was transfected in MDA-MB-231 cells prior to treatment with different concentrations of melatonin, it was revealed that luciferase activities were increased by treatment with $1 \mathrm{nM}$ to $1 \mu \mathrm{M}$ melatonin (Fig. 3B). When this region was analyzed in silico, the GATA binding site was identified. A previous study revealed that the zebra fish KiSS1 promoter contains a GATA binding site (45). Thus, the association between melatonin and GATA3 in transcriptional regulation of the KiSS1 gene expression was also examined. Consistently, in the chromatin immunoprecipitation assays, melatonin induced GATA3 interaction with the KiSS1 promoter region in MDA-MB-231 cells (Fig. 3C). Therefore, these data indicated that melatonin activated KiSS1 expression at a transcriptional level.

Melatonin inhibits breast cancer cell invasiveness via GATA3-dependent KiSS1 expression. GATA3 overexpression has been revealed to inhibit metastasis of MDA-MB-231 cells. Therefore, whether GATA3-induced KiSS1 expression is required to inhibit the invasiveness of breast cancer cells was investigated. In MDA-MB-231 cells, GATA3 overexpression increased the luciferase activity of pKiSS1-900-luc (Fig. 4A). Accordingly, it was revealed that GATA3 overexpression in MDA-MB-231 cells increased KiSS1 and GATA3 expression (Fig. 4B). Thus, the present study also examined whether
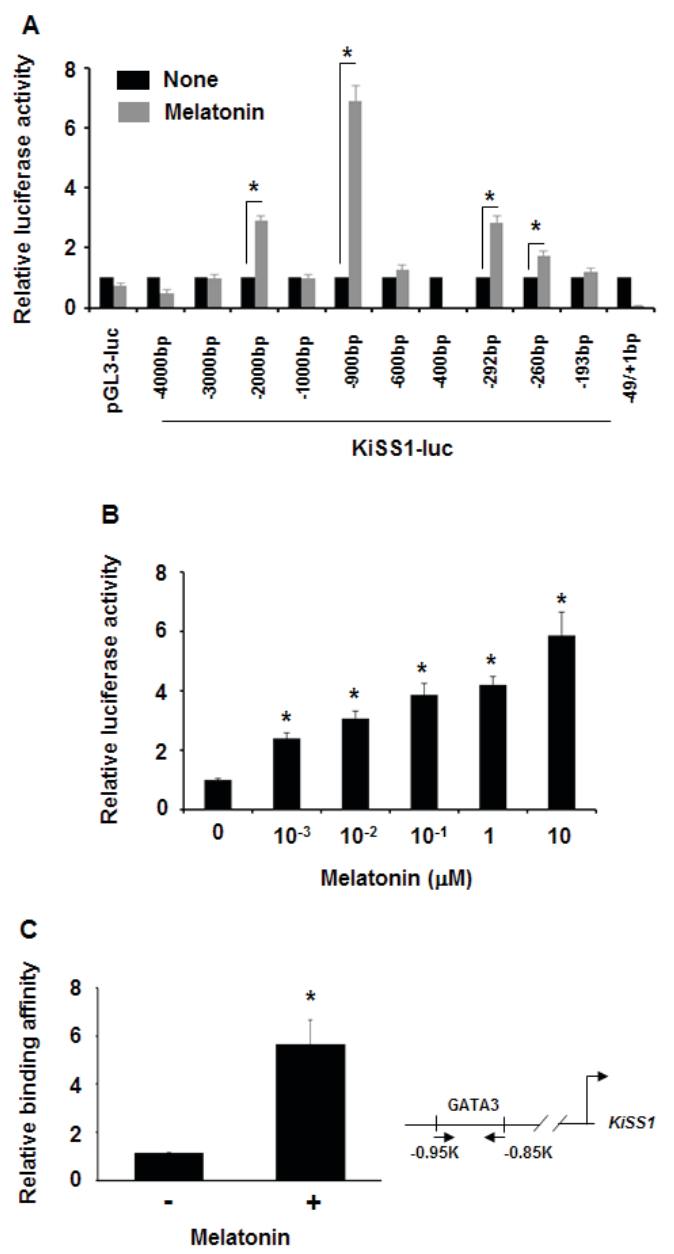

Figure 3. Melatonin activates GATA3-mediated KiSS1 expression. (A) 293T cells with different KiSS1 promoter regions were treated with $10 \mu \mathrm{M}$ melatonin for $12 \mathrm{~h}$ and then subjected to luciferase assays. Data are presented as the mean \pm standard error. (B) MDA-MB-231 cells with luciferase plasmids containing the $-900 \mathrm{bp} \mathrm{KiSS1}$ promoter region were treated with the indicated concentrations of melatonin for $12 \mathrm{~h}$, and then subjected to luciferase assays. Data are presented as the mean \pm standard error. (C) MDA-MB-231 cells were treated with $10 \mu \mathrm{M}$ melatonin for $12 \mathrm{~h}$, and then subjected to chromatin immunoprecipitation assays for GATA3 interaction with the KiSS1 promoter. The illustration represents a region for chromatin immunoprecipitation. Data are presented as the mean \pm standard deviation. ${ }^{*} \mathrm{P}<0.05$ vs. $0 \mu \mathrm{M}$. GATA3 GATA binding protein 3; KiSS1, kisspeptin.

GATA3 regulated MDA-MB-231 cell invasion. When GATA3 was overexpressed in MDA-MB-231 cells, the number of invading cells was reduced by $\sim 62 \%$ (Fig. 4C).

Whether melatonin-induced KiSS1 expression is required for the inhibition of the invasiveness was then examined. When KiSS1 was silenced in MDA-MB-231 cells with KiSS1 siRNA, melatonin failed to inhibit the invasiveness (Fig. 4D). In addition, melatonin increased GATA3 protein levels when MDA-MB-231 cells were treated with melatonin (Fig. 4E). Therefore, these results suggested that melatonin repressed the invasiveness via GATA3-mediated KiSS1 expression.

\section{Discussion}

The present study revealed how melatonin prolongs its inhibitory effect on the invasiveness of triple-negative breast cancer cells. Melatonin induced GATA3-mediated KiSS1 expression 
A

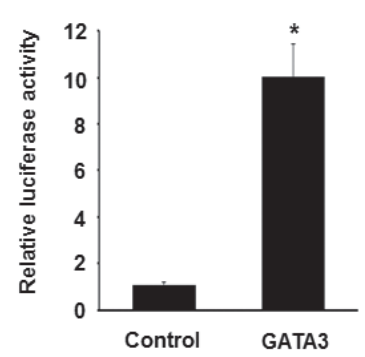

C

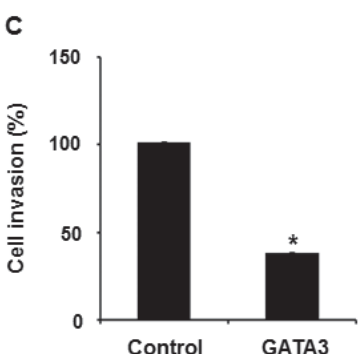

D

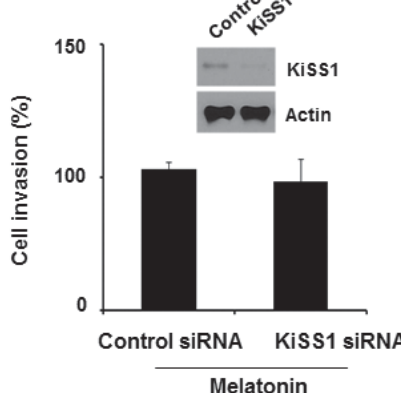

E

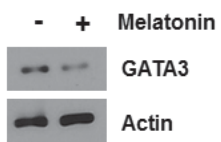

Figure 4. Melatonin maintains its inhibitory effect via GATA3-mediated KiSS1 expression. (A) MDA-MB-231 cells were transfected with GATA3 and KiSS1-luciferase plasmids, and then subjected to luciferase assays. MDA-MB-231 cells overexpressing GATA3 were then subjected to (B) western blot analysis or (C) invasion assays. (D) MDA-MB-231 cells were transfected with KiSS1 siRNA, treated with $10 \mu \mathrm{M}$ melatonin, and then subjected to invasion assays. KiSS1 knockdown was confirmed by western blotting. (E) MDA-MB-231 cells were treated with $10 \mu \mathrm{M}$ melatonin for $1 \mathrm{~h}$, and then GATA3 protein expression was examined. "P $<0.05$ vs. control. Data are presented as the mean \pm standard deviation. GATA3, GATA binding protein 3; KiSS1, kisspeptin; si, small interfering.

in triple-negative breast cancer cells. Consequently, KiSS1 maintained a melatonin-induced inhibitory effect.

MT1 deficiency in metastatic breast cancercells may explain why melatonin fails to inhibit proliferation (33). However, previous studies have demonstrated that melatonin inhibited the metastatic abilities of MDA-MB-231 breast cancer cells by inhibiting either Rho-associated protein kinase 1 or p38 mitogen-activated protein kinases $(31,32,46)$. Likewise, the results of the present study revealed that melatonin inhibited the invasiveness of triple-negative breast cancer cells with no effect on proliferation. In addition, melatonin was revealed to maintain its inhibitory effect by inducing KiSS1 expression. Likewise, KiSS1 silencing prevented melatonin-induced inhibition of invasiveness. KiSS1 is known to inhibit the metastatic abilities of cancer cells including the invasiveness (20). Thus, KiSS1 appears to prolong the inhibitory effect of melatonin on the invasiveness of breast cancer cells via GATA3 transcriptional activation.

The present study demonstrated that melatonin promoted KiSS1 expression in triple-negative breast cancer cells. As a disruption of light cycles increases the risk of breast cancer $(13,47,48)$, it is plausible that melatonin and KiSS1 may exhibit similar expression patterns in breast cancer. Melatonin has been revealed to regulate circadian rhythms by inhibiting KiSS1 expression in the brain of rodents (27). However, melatonin induces KiSS1 expression in fish, and vice versa $(49,50)$. Therefore, the mechanisms that result in the different effects of melatonin on KiSS1 expression in different experimental conditions, including animal models, remain unknown. The present study demonstrated that melatonin activated GATA3-mediated KiSS1 expression in triple-negative breast cancer cells. Previous in situ hybridization assays have revealed GATA3 expression in the hypothalamus of C57B6 mouse brains (51). Therefore, GATA3 may regulate melatonin-induced KiSS1 expression differently in the brain. Nevertheless, it remains to be determined how melatonin differentially regulates KiSS1 expression via GATA3 in different cells and/or tissues.

In conclusion, the present study suggested that melatonin prolongs its anti-metastatic effect by activating GATA3-mediated KiSS1 expression. While the effect of melatonin on breast cancer has been examined, to the best of our knowledge the present study is the first to reveal the effect of melatonin on triple-negative breast cancer cells.

\section{Acknowledgements}

The present study was supported by Korea National University of Transportation in 2015, and partly by Basic Science Research Program through the National Research Foundation of Korea funded by the Ministry of Science, ICT and Future Planning (grant no. NRF-2014R1A1A1035831).

\section{References}

1. Brainard GC, Hanifin JP, Greeson JM, Byrne B, Glickman G, Gerner E and Rollag MD: Action spectrum for melatonin regulation in humans: Evidence for a novel circadian photoreceptor. J Neurosci 21: 6405-6412, 2001.

2. Lerner AB, Case JD and Takahashi Y: Isolation of melatonin and 5-methoxyindole-3-acetic acid from bovine pineal glands. J Biol Chem 235: 1992-1997, 1960.

3. Stehle JH, von Gall C and Korf HW: Melatonin: A clock-output, a clock-input. J Neuroendocrinol 15: 383-389, 2003.

4. Hastings MH, Reddy AB and Maywood ES: A clockwork web: Circadian timing in brain and periphery, in health and disease. Nat Rev Neurosci 4: 649-661, 2003.

5. Slominski RM, Reiter RJ, Schlabritz-Loutsevitch N, Ostrom RS and Slominski AT: Melatonin membrane receptors in peripheral tissues: Distribution and functions. Mol Cell Endocrinol 351: 152-166, 2012.

6. Claustrat B, Brun J and Chazot G: The basic physiology and pathophysiology of melatonin. Sleep Med Rev 9: 11-24, 2005.

7. Dubocovich ML, Delagrange P, Krause DN, Sugden D, Cardinali DP and Olcese J: International union of basic and clinical pharmacology. LXXV. Nomenclature, classification, and pharmacology of $\mathrm{G}$ protein-coupled melatonin receptors. Pharmacol Rev 62: 343-380, 2010.

8. Acuña-Castroviejo D, Escames G, Venegas C, Díaz-Casado ME, Lima-Cabello E, López LC, Rosales-Corral S, Tan DX and Reiter RJ: Extrapineal melatonin: Sources, regulation, and potential functions. Cell Mol Life Sci 71: 2997-3025, 2014.

9. Burstein HJ, Polyak K, Wong JS, Lester SC and Kaelin CM: Ductal carcinoma in situ of the breast. N Engl J Med 350: 1430-1441, 2004.

10. Pagani O, Senkus E, Wood W, Colleoni M, Cufer T, Kyriakides S, Costa A, Winer EP and Cardoso F; ESO-MBC Task Force: International guidelines for management of metastatic breast cancer: Can metastatic breast cancer be cured? J Natl Cancer Inst 102: 456-463, 2010. 
11. Virnig BA, Tuttle TM, Shamliyan T and Kane RL: Ductal carcinoma in situ of the breast: A systematic review of incidence, treatment, and outcomes. J Natl Cancer Inst 102: 170-178, 2010.

12. Rabstein S, Harth V, Justenhoven C, Pesch B, Plöttner S, Heinze E, Lotz A, Baisch C, Schiffermann M, Brauch H, et al: Polymorphisms in circadian genes, night work and breast cancer: Results from the GENICA study. Chronobiol Int 31: 1115-1122, 2014.

13. Van Dycke KC, Rodenburg W, van Oostrom CT, van Kerkhof LW, Pennings JL, Roenneberg T, van Steeg H and van der Horst GT: Chronically alternating light cycles increase breast cancer risk in mice. Curr Biol 25: 1932-1937, 2015.

14. Basler M, Jetter A, Fink D, Seifert B, Kullak-Ublick GA and Trojan A: Urinary excretion of melatonin and association with breast cancer: Meta-analysis and review of the literature. Breast Care (Basel) 9: 182-187, 2014.

15. Schernhammer ES and Hankinson SE: Urinary melatonin levels and breast cancer risk. J Natl Cancer Inst 97: 1084-1087, 2005.

16. Innominato PF, Lim AS, Palesh O, Clemons M, Trudeau M, Eisen A, Wang C, Kiss A, Pritchard KI and Bjarnason GA: The effect of melatonin on sleep and quality of life in patients with advanced breast cancer. Support Care Cancer 24: 1097-1105, 2016.

17. Hill SM, Belancio VP, Dauchy RT, Xiang S, Brimer S, Mao L, Hauch A, Lundberg PW, Summers W, Yuan L, et al: Melatonin: An inhibitor of breast cancer. Endocr Relat Cancer 22: R183-R204, 2015.

18. Kumar P and Aggarwal R: An overview of triple-negative breast cancer. Arch Gynecol Obstet 293: 247-269, 2016

19. Oprea-Ilies G, Haus E, Sackett-Lundeen L, Liu Y, McLendon L, Busch R, Adams A and Cohen C: Expression of melatonin receptors in triple negative breast cancer (TNBC) in African American and Caucasian women: Relation to survival. Breast Cancer Res Treat 137: 677-687, 2013

20. Cho SG, Li D, Tan K, Siwko SK and Liu M: KiSS1 and its G-protein-coupled receptor GPR54 in cancer development and metastasis. Cancer Metastasis Rev 31: 585-591, 2012.

21. Tena-Sempere M: Roles of kisspeptins in the control of hypothalamic-gonadotropic function: Focus on sexual differentiation and puberty onset. Endocr Dev 17: 52-62, 2010.

22. Papaoiconomou E, Lymperi M, Petraki C, Philippou A Msaouel P, Michalopoulou F, Kafiri G, Vassilakos G, Zografos G and Koutsilieris M: Kiss-1/GPR54 protein expression in breast cancer. Anticancer Res 34: 1401-1407, 2014.

23. Marot D, Bieche I, Aumas C, Esselin S, Bouquet C, Vacher S, Lazennec G, Perricaudet M, Kuttenn F, Lidereau R and de Roux N: High tumoral levels of Kiss1 and G-protein-coupled receptor 54 expression are correlated with poor prognosis of estrogen receptor-positive breast tumors. Endocr Relat Cancer 14: 691-702, 2007.

24. Kostadima L, Pentheroudakis G and Pavlidis N: The missing kiss of life: Transcriptional activity of the metastasis suppressor gene KiSS1 in early breast cancer. Anticancer Res 27: 2499-2504, 2007.

25. Stark AM, Tongers K, Maass N, Mehdorn HM and Held-Feindt J: Reduced metastasis-suppressor gene mRNA-expression in breast cancer brain metastases. J Cancer Res Clin Oncol 131: 191-198, 2005.

26. Revel FG, Saboureau M, Masson-Pévet M, Pévet P, Mikkelsen JD and Simonneaux V: Kisspeptin mediates the photoperiodic control of reproduction in hamsters. Curr Biol 16: 1730-1735, 2006.

27. Gingerich S, Wang X, Lee PK, Dhillon SS, Chalmers JA, Koletar MM and Belsham DD: The generation of an array of clonal, immortalized cell models from the rat hypothalamus: Analysis of melatonin effects on kisspeptin and gonadotropin-inhibitory hormone neurons. Neuroscience 162: 1134-1140, 2009.

28. Borin TF, Arbab AS, Gelaleti GB, Ferreira LC, Moschetta MG, Jardim-Perassi BV, Iskander AS, Varma NR, Shankar A, Coimbra VB, et al: Melatonin decreases breast cancer metastasis by modulating Rho-associated kinase protein-1 expression. J Pineal Res 60: 3-15, 2016.

29. Jardim-Perassi BV, Lourenco MR, Doho GM, Grígolo IH, Gelaleti GB, Ferreira LC, Borin TF, Moschetta MG and Pires de Campos Zuccari DA: Melatonin regulates angiogenic factors under hypoxia in breast cancer cell lines. Anticancer Agents Med Chem 16: 347-358, 2016.

30. Jardim-Perassi BV, Arbab AS, Ferreira LC, Borin TF, Varma NR, Iskander AS, Shankar A, Ali MM and de Campos Zuccari DA: Effect of melatonin on tumor growth and angiogenesis in xenograft model of breast cancer. PLoS One 9: e85311, 2014.
31. Mao L, Yuan L, Slakey LM, Jones FE, Burow ME and Hill SM Inhibition of breast cancer cell invasion by melatonin is mediated through regulation of the p38 mitogen-activated protein kinase signaling pathway. Breast Cancer Res 12: R107, 2010.

32. Ortiz-López L, Morales-Mulia S, Ramirez-Rodriguez G and Benitez-King G: ROCK-regulated cytoskeletal dynamics participate in the inhibitory effect of melatonin on cancer cell migration. J Pineal Res 46: 15-21, 2009.

33. Mao L, Yuan L, Xiang S, Zeringue SB, Dauchy RT, Blask DE, Hauch A and Hill SM: Molecular deficiency (ies) in MT melatonin signaling pathway underlies the melatonin-unresponsive phenotype in MDA-MB-231 human breast cancer cells. J Pineal Res 56: 246-253, 2014

34. Bresnick EH, Lee HY, Fujiwara T, Johnson KD and Keles S: GATA switches as developmental drivers. J Biol Chem 285: 31087-31093, 2010

35. Morceau F, Schnekenburger M, Dicato M and Diederich M: GATA-1: Friends, brothers, and coworkers. Ann NY Acad Sci 1030: 537-554, 2004.

36. Zheng R and Blobel GA: GATA transcription factors and cancer. Genes Cancer 1: 1178-1188, 2010.

37. Naylor MJ and Ormandy CJ: Gata-3 and mammary cell fate. Breast Cancer Res 9: 302, 2007.

38. Kouros-Mehr H, Kim JW, Bechis SK and Werb Z: GATA-3 and the regulation of the mammary luminal cell fate. Curr Opin Cell Biol 20: 164-170, 2008.

39. Oh DS, Troester MA, Usary J, Hu Z, He X, Fan C, Wu J, Carey LA and Perou CM: Estrogen-regulated genes predict survival in hormone receptor-positive breast cancers. J Clin Oncol 24: 1656-1664, 2006.

40. Engelsen IB, Stefansson IM, Akslen LA and Salvesen HB: GATA3 expression in estrogen receptor alpha-negative endometrial carcinomas identifies aggressive tumors with high proliferation and poor patient survival. Am J Obstet Gynecol 199: 543.e1-e7, 2008.

41. Demir H, Turna H, Can G and Ilvan S: Clinicopathologic and prognostic evaluation of invasive breast carcinoma molecular subtypes and GATA3 expression. J BUON 15: 774-782, 2010

42. Cimino-Mathews A, Subhawong AP, Illei PB, Sharma R, Halushka MK, Vang R, Fetting JH, Park BH and Argani P: GATA3 expression in breast carcinoma: Utility in triple-negative, sarcomatoid, and metastatic carcinomas. Hum Pathol 44: 1341-1349, 2013.

43. Livak KJ and Schmittgen TD: Analysis of relative gene expression data using real-time quantitative PCR and the 2(-Delta Delta C(T) method. Methods 25: 402-408, 2001.

44. Pfaffl MW: A new mathematical model for relative quantification in real-time RT-PCR. Nucleic Acids Res 29: e45, 2001.

45. Nocillado JN, Mechaly AS and Elizur A: In silico analysis of the regulatory region of the Yellowtail Kingfish and Zebrafish Kiss and Kiss receptor genes. Fish Physiol Biochem 39: 59-63, 2013.

46. Borin TF, Arbab AS, Gelaleti GB, Ferreira LC, Moschetta MG, Jardim-Perassi BV, Iskander AS, Varma NR, Shankar A, Coimbra VB, et al: Melatonin decreases breast cancer metastasis by modulating Rho-associated kinase protein-1 expression. J Pineal Res 60: 3-15, 2016.

47. Papantoniou K, Pozo OJ, Espinosa A, Marcos J, Castaño-Vinyals G, Basagaña X, Juanola Pagès E, Mirabent J, Martín J, Such Faro P, et al: Increased and mistimed sex hormone production in night shift workers. Cancer Epidemiol Biomarkers Prev 24: 854-863, 2015.

48. Stevens RG, Brainard GC, Blask DE, Lockley SW and Motta ME: Breast cancer and circadian disruption from electric lighting in the modern world. CA Cancer J Clin 64: 207-218, 2014.

49. Kim NN, Choi YU, Park HS and Choi CY: Kisspeptin regulates the somatic growth-related factors of the cinnamon clownfish Amphiprion melanopus. Comp Biochem Physiol A Mol Integr Physiol 179: 17-24, 2015.

50. Alvarado MV, Carrillo M and Felip A: Melatonin-induced changes in kiss/gnrh gene expression patterns in the brain of male sea bass during spermatogenesis. Comp Biochem Physiol A Mol Integr Physiol 185: 69-79, 2015.

51. Zhao GY, Li ZY, Zou HL, Hu ZL, Song NN, Zheng MH, Su CJ and Ding YQ: Expression of the transcription factor GATA3 in the postnatal mouse central nervous system. Neurosci Res 61: 420-428, 2008. 